\title{
Fluoride Fact on Human Health and Health Problems: A Review
}

\section{Sananda Dey, Biplab Giri}

Experimental Medicine \& Stem Cell Research Laboratory, Department of Physiology, West Bengal State University, Barasat, Kolkata 700 126, India

*Corresponding author: Biplab Giri, Experimental Medicine \& Stem Cell Research Laboratory, Department of Physiology, West Bengal State University, Barasat, Kolkata 700 126, India, Tel: +91 33-2524 1977; Fax: +91 33-2524 1977; E-mail: bgiri.emscrl@gmail.com

Received date: Dec 05, 2015; Accepted date: Dec 21, 2015; Published date: Dec 24, 2015

Copyright: (c) 2015 Sananda Dey and Biplab Giri. This is an open-access article distributed under the terms of the Creative Commons Attribution License, which permits unrestricted use, distribution, and reproduction in any medium, provided the original author and source are credited.

\section{Abstract}

Fluorine $\left(\mathrm{F}^{-}\right)$is a chemically reactive electronegative univalent gaseous halogen found in small amount in the water, air, plants and animals. Fluorine is essential for the maintenance and solidification of our bones and to prevent dental decay. It has beneficial effects on teeth and bones when it is present at low concentration in drinking water, but excessive exposure to fluoride in drinking-water, or in combination with exposure to fluoride from other sources, can give rise to a number of adverse effects which include teeth decay, osteoporosis and harm to kidney, bones, reproductive organs, nerve and muscle. Fluoride, when in excess, is known to interfere with thyroid gland function causing TSH elevation and lessen T3/T4 hormones in some populations which may be due to its antagonistic properties towards iodine. As an endocrine disruptor, $\mathrm{F}^{-}$ induces more toxic outcome in diabetic patients. Chronic $\mathrm{F}^{-}$exposure through drinking water may leads to insulin resistance in humans in addition to its hyperglycemic effect due to increased hepatic glycogenolysis. Fluoride also hinders glycolysis by inhibiting enolase enzyme and repressing insulin secretion from islets of Langerhans cells resulting in elevation of blood glucose level. High $\mathrm{F}^{-}$ exposure is also associated with increased levels of FSH and $\mathrm{LH}$, decreased estrogen and testosterone levels, disturbed androgen to estrogen ratios (A/E) and estrogen receptor to androgen receptor ratios (ER/AR). Decreased circulating testosterone concentrations were also reported in male skeletal fluorosis patients. The most significant consequences of fluoride exposures in male reproduction are: changes in the structure and functional activities of spermatozoa and disruption of spermatogenesis while in an experimental data involving female rats showed that high fluoride concentration lowers the pregnancy rate and the number of implantation. Most interestingly, recent research showed that exposure to high concentration of $\mathrm{F}^{-}$does have deleterious effect on the mental ability of children. A strong association between exposure to fluoride and low IQ was found and it was also noted that children who live in fluorosis prevalent areas have higher chances of developing a low IQ than those who live in normal areas. So it is clear that the severity of the above pathological conditions is dependent on the dose, duration and age of the individual. Therefore, to ensure whether people need any fluoride supplements or not, government should have to take initiative to prevent health problems due to deficiency or excess fluoride exposure. Evidence-wise further thorough research is essential based on scientific facts to enlighten best practices in the use of fluoride containing materials for the safety and security of public health.

Keywords: Fluoride; Fluorosis; Oral health; Thyrotoxicity; Infertility; Diabetes

\section{Abbreviations}

F': Fluoride; PPM: Parts Per Million; TSH: Thyroid Stimulating Hormone; ATPase: Adenosine-Tri-Phosphatase; FSH: Follicle Stimulating Hormone; LH: Luteinizing Hormone

\section{Introduction}

Fluorine is a univalent gaseous halogen, pale yellow-green in color and most chemically reactive electronegative of all other elements [1]. In aqueous solution fluorine is commonly found as fluoride $\left(\mathrm{F}^{-}\right)$. Fluorine is the world's 13th most abundant element and constitutes $0.08 \%$ of the earth crustand the lightest member of the halogen group. Soil contains approximately $330 \mathrm{ppm}$ of fluorine. Small amount of fluorine is naturally present in the water, air, plants and animals. As a result humans are exposed to fluorine through food, drinking water and breathing air. Fluorine is essential for the maintenance and solidification of our bones and prevents dental decay. However, if it is absorbed too frequently, it may act in reverse way causing teeth decay, osteoporosis and harm to kidney, bone, nerve and muscle also. According to WHO Guidelines for Drinking-water Quality, the optimal value of fluoride in drinking water is $1.5 \mathrm{mg} \mathrm{\textrm {L } ^ { - 1 }}$. Fluorine being the most electronegative of all the elements, possess a strong tendency to acquire a negative charge and in solution forms $\mathrm{F}^{-}$ ions. Fluoride ions have the same charge and nearly the same radius as hydroxide ions and may replace each other in mineral structures [2]. Fluoride is one of the very few that has been shown to cause significant effects in population through many 
ways viz. drinking water, air, dental products, food, beverages and salts. It has beneficial effects on teeth \& bones when it is present at low concentration in drinking water, but excessive exposure to fluoride in drinking-water, or in combination with other sources, can give rise to a number of adverse effects. The adverse effects range from mild dental fluorosis to crippling skeletal fluorosis as the level and period of exposure increases. Crippling skeletal fluorosis is a significant cause of morbidity in a number of regions of the world. From several studies, it was observed that the average daily dietary intake of fluoride by children residing in fluoridated (1 ppm) communities is $0.05 \mathrm{mg} / \mathrm{kg} / \mathrm{day}$; in communities without optimally fluoridated water, average intakes for children are about $50 \%$ lower. Dietary fluoride intake by adults in fluoridated (1 ppm) areas averages 1.4-3.4 mg/day while in non-fluoridated areas it averages $0.3-1.0 \mathrm{mg} /$ day [3]. Fluorosis affects nearly one in every four Americans aged 6 to 49 years. It is the most prevalent in the ages between 12 to 15 years. A major cause of fluorosis is the inappropriate use of fluoridecontaining dental products such as toothpaste and mouth rinses [4]. Our concern while writing this review remains with how we can get the beneficial effects of fluoride without being exposed to the adverse consequences of using excess of it in the modern day.

\section{Worldwide Distribution of Fluorine}

The sources of fluoride in water are mostly geogenic, although important contributions also come from coal burning and industrial activities. Among them, micas, apatites and fluorite are the most common minerals which are responsible for fluoride in natural waters. Fluoride is also commonly associated with volcanic activity. The main geochemical processes that affect the content of fluoride in natural environments are the dissolution and precipitation of fluorine containing minerals and the adsorption/desorption from metal hydroxides and clay minerals. Most of the world's high-fluoride regions coincide with areas affected by volcanic activity regions underlain by crystalline igneous and metamorphic rocks, and large sedimentary basins in arid and semi-arid conditions. Among them significant zones include the Pacific volcanic belt, cratonic areas in central Africa, Asia and North and South America, the East African Rift valley, the large sedimentary basins in southern South America. There are another belts from Turkey through Iraq, Iran, Afghanistan, India, northern Thailand, China and the infertile region on the border between USA and Mexico [5]. Fluoride is found in all natural waters at some concentration. Seawater typically contains about $1 \mathrm{mg} \mathrm{I}^{-1}$ while rivers and lakes generally exhibit concentrations of less than $0.5 \mathrm{mg} \mathrm{l}^{-1}$. In ground waters, however, low or high concentrations of fluoride can occur, depending on the nature of the rocks and the occurrence of fluoride-bearing minerals.

\section{Beneficial Effect of Fluoride upon Dental Health}

Dental caries remains the most common chronic disease of childhood in the world. Fluoride has proven effectiveness in the prevention of caries and providing maximum protection against dental caries while minimizing the likelihood of enamel fluorosis. Regular fluoride exposure during the time of teeth development contributes to long lasting protection against enamel fluorosis and dental decay (Table 1). Enamel is a calcium-deficient, carbonate-rich hydroxyapatite. In its stable state, there is sufficient $\mathrm{Ca}^{2+}, \mathrm{PO}_{4}{ }^{3-}, \mathrm{OH}^{-}$and $\mathrm{F}^{-}$ion in the immediate vicinities of the crystals to maintain equilibrium with the surrounding fluid. During cariogenic acid attack, plaque bacteria form organic acids from carbohydrates as the acids dissociate releasing $\mathrm{H}^{+}$ions and lowers $\mathrm{pH}$ in the surroundings of the tooth. The $\mathrm{H}^{+}$ions protonate phosphate ions $\left(\mathrm{PO}_{4}{ }^{3-}\right)$ present in plaque fluid to $\mathrm{HPO}_{4}{ }^{2-}$ and particularly to $\mathrm{H}_{2} \mathrm{PO}_{4}^{-}$. This process also maintains neutrality and finally leads to the release of calcium from hard tooth substance [6]. Small amounts of fluoride in solution around the tooth inhibit demineralization more effectively than incorporated fluoride and have a much greater caries-protective potential than a large proportion of fluorohydroxyapatite in enamel. The hypothesis behind this protection is the free fluoride ions in solution around the tooth or enamel crystals play a much more important role in caries prevention than fluorides incorporated in the enamel crystals. Under these conditions, fluoride ions are in part adsorbed onto the crystalline surface and are in dynamic equilibrium with the fluoride ions in solution in the immediate environs. This leads to an equilibrium or supersaturation relative to fluorohydroxyapatite and hence to reprecipitation of minerals. Additionally, the adsorption of fluoride, on the crystals offers direct protection from demineralization. The enamel crystals can be locally dissolved during an acid attack if fluoride is absent for the long time. These low fluoride concentrations are also attained after consuming foods containing fluoridated table salt, since the $\mathrm{F}^{-}$ content of saliva significantly increases for about 30 minutes after such meals [7]. It can be inferred that fluoridated drinking water and table salt also function according to this mechanism, since the formation of $\mathrm{CaF}_{2}$ at these low concentrations is quite unlikely. Fluoride has antimicrobial effect too. In the laboratory, it was shown that the carbohydrate metabolism of oral streptococci and lactobacilli can be inhibited by fluoride [8]. In the cell, fluoride can inhibit two enzymes: enolase and the proton releasing adenosine-triphosphatase (ATPase). The over-acidification of the cytoplasm can also inhibit the mechanism of glucose transport into the cell [9]. However, reports in recent past revealed the excessive exposure of fluoride to have certain deleterious effects on the oral health, which we have discussed here in the following text. 
Table 1 Beneficial and adverse effects of fluoride on physiological health.

\begin{tabular}{|c|c|c|}
\hline Fluoride concentrations & Exposure & Physiological effects \\
\hline Greater than $1 \mathrm{ppm}$ & Chronic & Impaired glucose metabolism in both animals and humans [10]. \\
\hline Greater than $4 \mathrm{ppm}$ & Chronic & $\begin{array}{l}\text { Skeletal fluorosis, dental fluorosis hypo-mineralization of tooth enamel } \\
\text { [11]. }\end{array}$ \\
\hline \multirow{2}{*}{$\begin{array}{l}\text { Sub-acute exposure to } \\
\text { fluoride at a dose of } 20 \\
\text { ppm/day (orally to rat) }\end{array}$} & \multirow[t]{2}{*}{ Chronic } & $\begin{array}{l}\text { Induces thyroidal dysfunction including suppressed synthetic machinery } \\
\text { of the thyroid gland to produce thyroid hormones, mainly } \mathrm{T} 3 \text { and } \mathrm{T} 4 \text {. }\end{array}$ \\
\hline & & $\begin{array}{l}\text { Alteration of } \mathrm{Na}^{+}-\mathrm{K}^{+} \text {-ATPase, thyroid peroxidase, and } 5,5^{\prime} \text {-deiodinase } \\
\text { [12]. }\end{array}$ \\
\hline $100-200$ ppm & Chronic & $\begin{array}{l}\text { Changes on the thyroid hormone status, the histopathology of discrete } \\
\text { brain regions, the acetylcholine esterase activity and the learning and } \\
\text { memory abilities in multi-generation rats. [13] }\end{array}$ \\
\hline High fluoride & Chronic & Increases risk of Alzheimer's disease [14]. \\
\hline \multirow[t]{5}{*}{ High fluoride } & \multirow[t]{5}{*}{ Chronic } & Increased levels of FSH and LH $[15,16]$ \\
\hline & & Decreased estrogen levels [17], \\
\hline & & $\begin{array}{l}\text { Decreased testosterone levels and changes in its conversion into its } \\
\text { potent metabolites }[15,16,18] \text {, }\end{array}$ \\
\hline & & Reduced thyroid hormones [19-21], \\
\hline & & $\begin{array}{l}\text { Disturbed androgen to estrogen ratios }(A / E) \text { and estrogen receptor to } \\
\text { androgen receptor ratios (ER/AR) [22-24]. }\end{array}$ \\
\hline $\begin{array}{ll}1,000-1,500 & \mathrm{ppm} \quad \text { (in } \\
\text { toothpastes) } & \end{array}$ & Chronic & Prevent caries in permanent teeth [25]. \\
\hline \multirow{2}{*}{$\begin{array}{l}\text { Greater than } 1,000-1,500 \\
\text { ppm (in toothpastes) }\end{array}$} & Chronic & Enamel fluorosis of the front permanent incisors [11]. \\
\hline & Regular exposure during teeth development & Protection against enamel fluorosis in adult age also [6]. \\
\hline $\begin{array}{l}1.5 \mathrm{mg} / \mathrm{L} \text { or above } \\
\text { (through water) }\end{array}$ & Daily intake & Produces insulin resistance [26]. \\
\hline $\begin{array}{l}0.05-0.07 \mathrm{mg} / \mathrm{kg} \text { body } \\
\text { weight (should not exceed } \\
\text { from all sources) }\end{array}$ & Daily & $\begin{array}{l}\text { In order to minimize the risk of dental fluorosis (Canadian Dental } \\
\text { Association 2012). }\end{array}$ \\
\hline
\end{tabular}

\section{Fluoride and Alteration of Thyroid Function}

The increasing use of fluoride for prevention of dental caries poses the problem as to whether this halogen has antagonistic properties towards iodine. Fluoride, when in excess, is known to interfere with thyroid gland function. The thyroid gland appears to be the most sensitive tissue in the body to $\mathrm{F}^{-}$[27]. High fluoride concentration (100 - 200 ppm) induces changes on the thyroid hormone status, the histopathology of discrete brain regions, the acetylcholine esterase activity and the learning and memory abilities in multi-generation rats [13]. Fluoride is able to increase the concentration of thyroid stimulating hormone (TSH) and decrease the concentration of T3 and T4 hormones, thereby producing hypothyroidism in some populations [28]. Accordingly, prolonged utilization of high $\mathrm{F}^{-}$water has the potential to suppress the function of the thyroid gland. Changes in the thyroid hormone level results in the imbalance of oxidant/antioxidant system, resulting to a reduction in learning memory abilities [13]. Experimental evidences showed that sub-acute exposure to sodium fluoride at a dose of $20 \mathrm{ppm}$ per day orally to rat for 30 days induces thyroidal dysfunction including suppressed synthetic (C) Copyright iMedPub machinery of the thyroid gland to produce nucleic acids and thyroid hormones, mainly T3 and T4. Other functional changes are alteration of certain metabolic enzyme activities like $\mathrm{Na}(+)-$ $\mathrm{K}(+)$-ATPase, thyroid peroxidase, and 5,5'-deiodinase. Structural abnormality of thyroid follicles by fluoride intoxication clearly indicates its thyrotoxic manifestation (Table 1) [12].

\section{Fluoride, Insulin Secretion and Diabetes}

Fluoride is a low-dose endocrine disruptor whose toxicity is greater in diabetic patients. Various researchers' study came to a point that insulin resistance in humans caused by chronic fluoride exposure from drinking water [29-33]. According to The US National Research Council [10], impaired glucose metabolism appears to be associated with serum or plasma fluoride concentrations of about $0.1 \mathrm{ppm}$ or greater in both animals and humans. Diabetics also suffer reduced bone mass and strength through fluoride exposure. Fluoride induced hyperglycemia has been stated to be mainly due to increased hepatic glycogenolysis [34]. Fluoride ion inhibits glycolysis by inhibiting enolase resulting in accumulation of 2- 
phosphoglycerate therefore increases and as it does so, is equilibrated with 3-phosphoglycerate by the enzyme phosphoglucomutase. As a result of this blood glucose level increases [35]. The impact of fluoride on diabetic patients is much adverse because they typically consume much larger quantities of water than average humans and accumulate more fluoride [36] which leads to higher risk of impaired renal function [37]. Increased capillary permeability, microcirculatory defects and altered protein biosynthesis in the pancreas are also associated with fluoride exposure [38]. Fluoride also causes hypo-thyroidisms which also affect diabetics through reduction of peripheral glucose metabolism [39]. In an in vitro experiment using isolated Islets of Langerhans cells, both basal and glucose-stimulated insulin secretion is repressed as the fluoride concentrations increases [40]. Interestingly, fluoride expedites the mRNA expression of insulin receptor (InsR) in vitro. A close and inverse relationship exists between insulin secretion and blood fluoride level [41]. So, excess fluoride exposure might be a silent cause of recent worldwide rise in diabetic population (Table 1).

\section{Fluoride Effect on Reproductive Health}

The effects of fluoride on female and male fertility are now considered to be a factor causing infertility problems, which are at present a growing concern by the scientific community. An epidemiological study to review whether fluoride could affect human reproductive health using U.S. database of drinking water systems demonstrated an alliance of lessening total fertility rate with rising fluoride levels in both male and female individuals [42]. Increased exposure to fluoride $\left(\mathrm{F}^{-}\right)$may cause serious toxic effects. The available research indicates that high $\mathrm{F}^{-}$exposure is associated with the increased levels of follicle stimulating hormone (FSH) and luteinizing hormone (LH) $[15,16]$ decreased estrogen levels [17], decreased testosterone levels and changes in its conversion into its potent metabolites $[15,16,18]$, reduced thyroid hormones [19-21], disturbed androgen to estrogen ratios (A/E) and estrogen receptor to androgen receptor ratios (ER/AR) [22-24]. The most significant consequences of fluoride exposures in male reproduction are: changes in the structure and functional activities of spermatozoa, disruption of spermatogenesis, and instability of multiple hormone systems. Decreased circulating testosterone concentration was also reported in male skeletal fluorosis patients [43]. An experimental data, involving female rats, showed that, high fluoride concentration lowers the pregnancy rate and the number of implantation as well [44]. Such disturbances in reproductive and endocrine systems would probably contribute to more reproductive health problems at present days (Table $\mathbf{1}$ ).

\section{Fluoride Effect on Neuronal Health}

Fluoride may cause neurotoxicity in laboratory animals including effects on learning and memory. Fluoride concentration above $1 \mathrm{mg} / \mathrm{L}$ develops neurotoxicity [45]. Fluoride exposure to the developing brain is much more vulnerable to damage by toxicants than in case of mature brain and may possibly leads to permanent damage to the developing brain [46]. Recent research showed that exposure to high concentration of fluoride does have deleterious effect on the mental ability of the children [47]. In a meta-analysis performed in China, to review studies on fluoride and IQ between 1988 and 2008, a steady and a strong association between exposure to fluoride and low IQ was found and it was also noted that children who live in fluorosis prevalent areas have five times higher chances of developing a low IQ than those who live in having less fluorosis areas [45]. On the contrary, from an epidemiological study it was found that a high-fluoride area had one-fifth the Alzheimer's that a lowfluoride area had [14]. This inverse relationship between the possibility of the onset of Alzheimer's disease and the IQ changes need further clarification to understand whether fluoride alone involved or in addition other factors come in to play too for such outcomes (Table 1).

\section{Fluoride Effect on Skeletal and Dental Health}

Fluorosis a chronic condition caused by excessive intake of fluorine compounds marked by mottling of the teeth and, if severe, calcification of the ligaments. Fluorosis is mainly of two types' viz., skeletal fluorosis and dental fluorosis. Toxic levels of fluoride have been coupled with a weakening of bones and an increase in hip and wrist fractures. The U.S. National Research Council concludes that fractures are mostly associated with the fluoride levels of 1-4 ppm. Consumption of fluoride at levels beyond this in fluoridated water for a long period of time causes skeletal fluorosis. In some areas, particularly the Asian subcontinent, skeletal fluorosis is prevalent. Early stages are not clinically apparent and may be mis-diagnosed as rheumatoid arthritis or ankylosing spondylitis (National Research Council 2006). Dental fluorosis is hypo-mineralization of tooth enamel caused by intake of too much fluoride during enamel formation [11]. It appears as a range of visual changes in enamel resulting degrees of intrinsic tooth discoloration. The severity of the condition is dependent on the dose, duration and age of the individual [48]. In the mildest form (most common form) there are faint white lines or specks. Slightly more severe cases appear as white mottled patches, while severe fluorosis is characterized by brown discoloration and brittle, pitted and rough enamel.

Dental fluorosis is hypo mineralization of tooth enamel caused by ingestion of excessive fluoride during enamel formation. In the extra-cellular environment of maturing enamel, an excess of fluoride ions changes the rate at which enamel matrix proteins (amelogenin) are enzymatically broken down and the rate at which the subsequent breakdown products are removed. Fluoride may also indirectly alter the action of protease via a decrease in the availability of free calcium ions in the mineralization environment [49]. This results in the formation of enamel with less mineralization. This hypo-mineralized enamel has altered optical properties and appears opaque and lusterless relative to normal enamel. Barring the most severe cases, teeth with fluorosis are 
relatively resistant to dental caries (tooth decay), although they may be of potential cosmetic concern [50]. A number of other adverse effects have also been reported, viz., increased hepatic cell size, nephrosis, myocardial mineralization and degeneration of the seminiferous tubules in testis [51]. The majority of fluoride is excreted via the kidneys [52] therefore it is logical that those with impaired renal function might be at greater risk of fluoride toxicity (Table $\mathbf{1}$ ).

\section{Tooth Paste Really Needs that Much Fluoride?}

A number of systematic reviews suggested that toothpastes with a low fluoride concentration of $250 \mathrm{ppm} \mathrm{F}^{-}$are less effective than toothpastes with the standard 1,000-1,500 ppm fluoride at preventing caries in permanent teeth [25]. Since young infants and children under age 2 years can swallow most of the toothpaste while brushing, parents must be careful about the use of fluoride containing toothpaste with the fluoride level of 1,000-1,500 ppm, since it could give rise to enamel fluorosis of the front permanent incisors [11]. Enamel fluorosis is a condition which involves from minor white spots to unsightly yellow/ brown discoloration of the enamel, caused by excessive intake of fluoride. As a corrective measure against enamel fluorosis, some manufacturers are now produces low fluoride (less than $600 \mathrm{ppm}$ ) containing pediatric toothpastes. So, the use of fluoridated toothpaste in children has to be recommended by the experts after a thorough calibration which aims to minimize the risk of fluorosis from fluoride toothpaste while maximizing its caries-preventive benefits.

\section{Conclusion}

As a whole fluoride is one of the most beneficial micro nutrients for our body but in excess it can harm us in many ways. According to recommendation of World Health Organization total daily fluoride exposure would be approximately $0.6 \mathrm{mg} /$ adult/day in an area in which no fluoride is added to the drinking-water and $2 \mathrm{mg}$ per adult per day in a fluoridated area [5]. Therefore to get the beneficial effects of fluoride, people must be careful before consuming fluoridated water, foods, salt and using highly fluoridated tooth paste. Since young infants and children under age 2 years can swallow most of the toothpaste when brushing, parents should have to be careful. A low fluoride (less than 600 ppm) containing pediatric toothpastes can only be used for the children instead of fluoride toothpaste containing 1,000-1,500 ppm fluoride until new recommendation implemented. Government should monitor fluoride concentration in different sources of drinking water and ground water and thorough fluoride map should be available to the public. To ensure whether people need any fluoride supplements or not, Government should include the International/WHO guidelines in a circular form to prevent health problems due to deficiency or excess fluoride exposure. The guidelines must deliver an evidence-based summary of current research and facts to enlighten best practices in the use of fluoride containing materials for the safety and security of public health.

\section{References}

1. Hem JD (1989) Study and Interpretation of the Chemical Characteristics of Natural Water. (3rd edn) U.S Geological Survey Water-Supply Paper 2254, US Geological Survey, Washington, DC Pp: 263.

Brigatti MF, Guggenheim S (2002) Mica crystal chemistry and the influence of pressure, temperature, and solid solution on atomistic models. In: Mottana A, Sassi FP, Thompson Jr JB, Guggenheim S (eds). Micas: Crystal Chemistry \& Metamorphic Petrology. Mineralogical Society of America, Pp: 1-98.

3. NCBI Bookshelf (1997) Dietary Reference Intakes for Calcium, Phosphorus, Magnesium, Vitamin D, and Fluoride. Institute of Medicine (US) Standing Committee on the Scientific Evaluation of Dietary Reference Intakes. Washington (DC): National Academies Press (US)

4. Dean JA, (2015) McDonald and Avery's Dentistryfor the Child and Adolescent. (10th edn), Elsevier Health Sciences P: 132.

5. Dunipace AJ, Wilson CA, Wilson ME, Zhang W, Kafrawy AH, et al (2006) Fluoride in Drinking-water. World Health Organization (WHO).

6. Dawes C (2003) What is the critical pH and why does a tooth dissolve in acid? J Can Dent Assoc 69: 722-724.

7. Hedman J, Sjöman R, Sjöström I, Twetman S (2006) Fluoride concentration in saliva after consumption of a dinner meal prepared with fluoridated salt. Caries Res 40: 158-162.

8. Balzar Ekenbäck S, Linder LE, Sund ML, Lönnies H (2001) Effect of fluoride on glucose incorporation and metabolism in biofilm cells of Streptococcus mutans. Eur J Oral Sci 109: 182-186.

9. Sutton SV, Bender GR, Marquis RE (1987) Fluoride inhibition of proton-translocating ATPases of oral bacteria. Infect Immun 55: 2597-2603.

10. National Research Council (2006) Fluoride in DrinkingWater: A Scientific Review of EPA's Standards. Washington DC: National Academies Press.

11. Wong MC, Glenny AM, Tsang BW, Lo EC, Worthington HV, et al. (2010) Topical fluoride as a cause of dental fluorosis in children. Cochrane Database Syst Rev : CD007693.

12. Sarkar C, Pal S (2014) Ameliorative effect of resveratrol against fluoride-induced alteration of thyroid function in male wistar rats. Biol Trace Elem Res 162: 278-287.

13. Basha PM, Rai P, Begum S (2011) Fluoride toxicity and status of serum thyroid hormones, brain histopathology, and learning memory in rats: a multigenerational assessment. Biol Trace Elem Res 144:1083-1094.

14. Li L (2003) The biochemistry and physiology of metallic fluoride: action, mechanism, and implications. Crit Rev Oral Biol Med 14: 100-114.

15. Ortiz-Pérez $D$, Rodríguez-Martínez $M$, Martínez F, Borja-Aburto VH, Castelo J, et al. (2003) Fluoride-induced disruption of reproductive hormones in men. Environ Res 93: 20-30.

16. Tokar' VI, Savchenko ON (1977) [Effect of inorganic fluorine compounds on the functional state of the pituitary-testis system]. Probl Endokrinol (Mosk) 23: 104-107. 
17. Jiang CX, Fan QT, Cheng XM, Cui LX (2005) [Relationship between spermatogenic cell apoptosis and serum estradiol level in rats exposed to fluoride]. Wei Sheng Yan Jiu 34: 32-34.

18. Chinoy NJ, Narayana MV, Sequeira E, Joshi SM, Barot JM, et al. (1992) Studies oneffects of fluoride in 36 villages of Mehsana District, North Gujarat. Fluoride 25: 101-110..

19. Bobek S, Kahl S, Ewy Z (1976) Effect of long-term fluoride administration on thyroid hormones level blood in rats. Endocrinol Exp 10: 289-295.

20. Bachinskï̈ PP, Gutsalenko OA, Naryzhniuk ND, Sidora VD, Shliakhta Al (1985) [Action of the body fluorine of healthy persons and thyroidopathy patients on the function of hypophyseal-thyroid the system]. Probl Endokrinol (Mosk) 31: 25-29.

21. Wang H, Yang Z, Zhou B, Gao H, Yan X, et al. (2009) Fluorideinduced thyroid dysfunction in rats: roles of dietary protein and calcium level. Toxicol Ind Health 25: 49-57.

22. Andò $S$, Sirianni $R$, Forastieri $P$, Casaburi $I$, Lanzino $M$, et al. (2001) Aromatase expression in prepuberal Sertoli cells: effect of thyroid hormone. Mol Cell Endocrinol 178: 11-21.

23. Palmero S, Prati M, Bolla F, Fugassa E (1995) Tri-iodothyronine directly affects rat Sertoli cell proliferation and differentiation. J Endocrinol 145: 355-362.

24. Pezzi V, Panno ML, Sirianni R, Forastieri P, Casaburi I, et al. (2001) Effects of tri-iodothyronine on alternative splicing events in the coding region of cytochrome $\mathrm{P} 450$ aromatase in immature rat Sertoli cells. J Endocrinol 170: 381-393.

25. Marinho VC, Higgins JP, Sheiham A, Logan S (2003) Fluoride toothpastes for preventing dental caries in children and adolescents. Cochrane Database Syst Rev 1: CD002278.

26. Lombarte M, Fina BL, Lupo M, Buzalaf MA, Rigalli A (2013) Physical exercise ameliorates the toxic effect of fluoride on the insulin-glucose system. J Endocrinol 218: 99-103.

27. Shashi A (1988) Biochemical effects of fluoride on thyroid gland during experimental fluorosis. Fluoride 21: 127-130.

28. McLaren JR (1976) Possible effects of fluorides on the thyroid. Fluoride 9: 105-116.

29. Bergman Ake, Heindel JJ, Jobling S, Karen A, Zoeller RT (2013) State of the Science of Endocrine Disrupting Chemicals-2012. An assessment of the state of the science of endocrine disruptors prepared by a group of experts for the United Nations Environment Programme and World Health Organization.

30. Vandenberg LN1, Colborn T, Hayes TB, Heindel JJ, Jacobs DR Jr, et al. (2012) Hormones and endocrine-disrupting chemicals: low-dose effects and nonmonotonic dose responses. Endocr Rev 33: $378-455$

31. Chiba FY, Garbin CAS, Sumida DH (2012) Effect of fluoride intake on carbohydrate metabolism, glucose tolerance, and insulin signaling. Fluoride 45: 236-241.

32. Stephen KW (1994) Fluoride toothpastes, rinses, and tablets. Adv Dent Res 8: 185-189.

33. Trivedi N, Mithal A, Gupta SK, Godbole MM (1993) Reversible impairment of glucose tolerance in patients with endemic fluorosis. Fluoride Collaborative Study Group. Diabetologia 36: 826-828.
34. Varadacharyulu NC, Rao PR (1997) Gluconeogenesis and glycogenolysis in fluoride-treated rats. Indian J Exp Biol 35: 906-908.

35. Qin J, Chai G, Brewer JM, Lovelace LL, Lebioda L (2006) Fluoride inhibition of enolase: crystal structure and thermodynamics. Biochemistry 45: 793-800.

36. Prystupa J (2011) A current literature review. An NRC and ATSDR based review of safety standards for exposure to fluorine and fluorides Toxicology Mechanisms and Methods. Fluorine 21: 103-170.

37. Banupriya CAY, Anitha K, Muralimohan E, Pillai KS, Murthy PB (1997) Toxicity of fluoride to diabetic rats. Fluoride 30: 43-50.

38. Rasmussen DD, Boldt BM, Wilkinson CW, Yellon SM, Matsumoto AM (1999) Daily melatonin administration at middle age suppresses male rat visceral fat, plasma leptin, and plasma insulin to youthful levels. Endocrinology 140: 1009-1012.

39. Cettour-Rose P, Theander-Carrillo C, Asensio CK, Visser TJ, Burger AG, et al. (2005) Hypothyroidism in rats decreases peripheral glucose utilisation, a defect partially corrected by central leptin infusion. Diabetologia 48: 624-633.

40. Rigalli A, Ballina JC, Puche RC (1992) Bone mass increase and glucose tolerance in rats chronically treated with sodium fluoride. Bone Miner 16: 101-108.

41. Hu CY, Ren LQ, Li XN, Wu N, Li GS, et al. (2012) Effect of fluoride on insulin level of rats and insulin receptor expression in the MC3T3-E1 cells. Biol Trace Elem Res 150: 297-305.

42. Freni SC (1994) Exposure to high fluoride concentrations in drinking water is associated with decreased birth rates. J Toxicol Environ Health 42: 109-112.

43. Susheela AK, Jethanandani P (1996) Circulating testosterone levels in skeletal fluorosis patients. J Toxicol Clin Toxicol 34: 183-189.

44. Al-Hiyasat AS, Elbetieha AM, Darmanib H (2000) Reproductive toxic effects of ingestion of sodium fluoride in female rats. Fluoride 33: 79-84.

45. Choi AL, Sun G, Zhang Y, Grandjean P (2012) Developmental fluoride neurotoxicity: a systematic review and meta-analysis. Environ Health Perspect 120: 1362-1368.

46. Grandjean P, Landrigan PJ (2006) Developmental neurotoxicity of industrial chemicals. Lancet 368: 2167-2178.

47. Shivaprakash PK, Ohri K, Noorani H (2011) Relation between dental fluorosis and intelligence quotient in school children of Bagalkot district. J Indian Soc Pedod Prev Dent 29: 117-120.

48. Bergc JH, Slayton RL (2015) Early Childhood Oral Health. John Wiley \& Sons P: 113.

49. Fejerskov-O-Kidd E (2009) Dental Caries: The Disease and Its Clinical Management. John Wiley \& Sons pp: 299-327.

50. Neville BW, Chi AC, Damm DD, Allen CM (2015) Oral and Maxillofacial Pathology. (4th edn) Elsevier Health Sciences. pp: 52-54.

51. IPCS (2002) Fluorides. Environmental Health Criteria 227. World Health Organization, Geneva.

52. USNRC (1993) Health Effects of Ingested Fluoride. US National Research Council, National Academy Press, Washington, D.C. 